\title{
Evaluasi Aktivitas Manual Material Handling dan Penerapan K3 Bagian Palletizing Kemasan Jerigen di PT. XYZ
}

\author{
Kusnadi Kusnadi*1, Aulia Fashanah Hadining ${ }^{2}$, dan Wahyudin Wahyudin ${ }^{3}$ \\ ${ }^{1}$ Program Studi Teknik Industri, Fakultas Teknik, Universitas Singaperbangsa Karawang, Jl. HS. Ronggo Waluyo, \\ Kecamatan Telukjambe Timur, Kabupaten Karawang, 41361, Indonesia \\ 2,3 Universitas Singaperbangsa Karawang, Jl. HS. Ronggo Waluyo, Kecamatan Telukjambe Timur, Kabupaten \\ Karawang, 41361, Indonesia \\ Email: tikuk.kusnadi@yahoo.com¹, aulia@gmail.com², hwwahyudin@gmail.com³
}

DOI: 10.20961/performa.19.1.42597

\begin{abstract}
Abstrak
Hasil produksi yang ditangani secara manual yaitu mengangkat beban kemasan jerigen dengan berat $24 \mathrm{~kg}$ dari conveyor ke palet. Proses pengangkatan ini berisiko pada muskulokeletal serta dapat menimbulkan nyeri punggung bagian bawah. Proses pengangkatan ini terjadi di bagian packing line D. Tujuan penelitian ini untuk mengetahui tingkat risiko, bentuk conveyor yang tidak sesuai dengan kondisi kerja dan rekomendasi tindakan perbaikan yang harus dilakukan ketika sikap kerja operator memiliki risiko cedera. Penilaian terhadap postur kerja berdasarkan penilaian dari RULA untuk setiap bagiannya (lengan atas, lengan bawah, pergelangan tangan, perputaran pergelangan tangan, punggung, leher, dan posisi kaki) yang selanjutnya dikategorikan berdasarkan hasil dari grand score pada action level yang menunjukkan bahwa postur tersebut diperlukan perbaikan atau tidak. Hasil penelitian ini diperoleh 3 pekerja untuk postur kerja grand score rata-rata 7 yang menunjukkan perlu tindakan sekarang juga. Hal tersebut dipengaruhi oleh beban yang berat dengan pengangkatan secara manual.
\end{abstract}

Kata kunci: Material Handling, RULA, Conveyor, Alat Pelindung Diri

\begin{abstract}
Production results that are handled manually are lifting jerry cans with a weight of $24 \mathrm{~kg}$ from the conveyor to the pallet. This removal process has musculosceletal risks and can cause lower back pain. This lifting process occurs in the packing line D section. The purpose of this study is to determine the level of risk, the shape of the conveyor that is not in accordance with working conditions and recommendations for corrective actions that must be taken when the work attitude of the operator has the risk of injury. Assessment of work posture is based on the assessment of RULA for each part (upper arm, forearm, wrist, wrist rotation, back, neck, and leg position) which is then categorized based on the results of the grand score at the action level which indicates that the posture is required. repair or not. The results of this study obtained 3 workers for the work posture of the grand score with an average of 7 which indicates that action is needed now. This is influenced by heavy loads with manual lifting.
\end{abstract}

Keywords: Material Handling, RULA, Conveyor, Personal Protective Equipment

\section{Pendahuluan}

Penangganan material secara manual merupakan aktivitas yang selalu ada dalam industri manufaktur dan industri pengolahan. Peranan manusia sebagai sumber tenaga kerja masih dominan dalam menjalankan proses produksi, terutama kegiatan yang bersifat manual. Salah satu bentuk peranan manusia adalah aktivitas pemindahan material secara manual (Manual Material Handling/MMH). Kelebihan manual material handling bila dibandingkan dengan penanganan material menggunakan alat bantu adalah pada fleksibilitas gerakan yang dapat dilakukan untuk beban-beban ringan. Akan tetapi aktivitas manual material handling dalam pekerjaanpekerjaan industri banyak diidentifikasi berisiko besar sebagai penyebab penyakit tulang belakang (low back poin) dan posisi tubuh yang salah dalam bekerja (Lueder, 1996).

Dalam perancangan sistem kerja harus memperhatikan prosedur-prosedur untuk membuat gerakan kerja yang memenuhi prinsip-prinsip ekonomi gerakan dan dengan memperhatikan kemampuan dan keterbatasan pekerja. Tempat kerja harus menyesuaikan dengan bentuk dan ukuran pekerja agar aktivitas manual material handling dilakukan dengan leluasa. Gerakan kerja yang memenuhi prinsip ekonomi gerakan dapat memperbaiki efisiensi kerja dan mengurangi kelelahan kerja. Sebaliknya, jika dalam perancangan sistem kerja yang tidak teratur atau tidak mempertimbangkan gerakan dan keterbatasan pekerja pada saat bekerja maka dapat menyebabkan terjadinya sikap tubuh yang tidak alamiah (Nurmianto, 1996).

\footnotetext{
${ }^{*}$ Penulis utama (Corresponding author)
} 
PT. XYZ merupakan perusahaan yang bergerak di bidang makanan dan minuman dengan jam kerja pada bagian produksi adalah 7 jam dan waktu istirahat selama satu jam, yaitu pukul 12:00-13:00. Salah satu produk yang dimiliki perusahaan ini adalah sambal, yang terdiri dari beberapa kemasan yaitu, $135 \mathrm{ml}, 195 \mathrm{ml}, 275 \mathrm{ml}$, $335 \mathrm{ml}, 600 \mathrm{ml}, 5,7 \mathrm{~kg}$, sampai dengan $24 \mathrm{~kg}$. Produk sambal tersebut melalui beberapa tahapan proses dimulai dari proses pencucian cabe yang telah di sortir kemudian diolah menjadi sambal dibagian blending hingga dikemas dibagian packing yang selanjutnya dikirim ke tangan konsumen.

Pekerjaan mengangkat produk kemasan jerigen $24 \mathrm{~kg}$ dilakukan secara manual tanpa adanya alat bantu. Sedangkan kapasitas produksi sambal dalam kemasan di PT. XYZ saat ini adalah 66 pallet setiap shift. Setiap pallet terdapat 32 jerigen sehingga operator harus mengangkat 2100 jerigen selama satu shift dengan waktu istirahat selama satu jam.

Untuk kelancaran proses produksi sambal, perusahaan telah memanfaatkan beberapa operator. Tenaga manusia digunakan pada bagian akhir proses yaitu pada pemindahan jerigen yang sudah berisi produk sambal dari conveyor ke pallet plastic untuk dikirmkan kebagian finish good. Akan tetapi, bentuk conveyor yang ada saat ini terlalu tinggi yang diduga menjadi salah satu penyebab keluhan operator. Seperti pada Tabel 4. di bawah ini.

Pada penelitian ini telah dilakukan evaluasi ergonomic pada aktivitas pengangkatan beban dibagian palletizing dan juga dirumuskan rekomendasi metode kerja yang lebih baik dan sesuai dengan prinsip-prinsip ergonomic kerja. Evaluasi dilakukan terhadap sikap kerja operator pada saat mengerjakan pekerjaannya sehinggan mengurangi resiko cedera. Oleh karena itu menggunakan metode RULA (Rapid Upper Limb Assesment) untuk proses analisis resiko cedera operator terutama pada tubuh bagian atas seperti lengan, pergelangan tangan siku, bahu serta leher dan punggung (Pourmahabadian, et al., 2008).

\section{Metode Penelitian}

Penelitian ini dilakukan menggunakan data yang dikumpulkan melalui wawancara, observasi, dan dokumen. Objek penelitian dalam judul ini secara keseluruhan berkaitan dengan kondisi yang dialami pekerja setelah bekerja beberapa lama di PT. XYZ. Jenis penelitian dalam analisis menggunakan data sekunder yang datanya diperoleh langsung dari perusahaan. Dalam penelitian ini yang menjadi variabel yaitu terdiri dari posisi tubuh pekerja saat $\mathrm{n}=$ melakukan pekerjaan yaitu gerakan berulang-ulang dan berat beban, keluhan subjektif dari para pekerja saat melakukan pekerjaan.

Objek penelitian ini yaitu pada bagian palleting produk di Line D yang dilakukan oleh operator. Operator yang diteliti adalah yang mempunyai keluhan saat bekerja maupun setelah bekerja. Jumlah pekerja yang diamati dan nilai tingkat risiko ergonominya. Postur kerja ketika seorang operator mengangkat produk sambal $\mathrm{ABC}$ kemasan jerigen $24 \mathrm{~kg}$ ini adalah postur kerja untuk melaksanakan tahapan dalam kegiatan palletizing. Postur kerja yang dimaksud adalah sebagai berikut (Nurmianto, 2004):

a. Postur kerja berdiri dengan tangan terlentang, elemen kegiatan mengangkat produk sambal kemasan jerigen $24 \mathrm{~kg}$ dari conveyor.

b. Postur kerja bungkuk pada elemen kegiatan penyimpanan produk sambal kemasan jerigen $24 \mathrm{~kg}$ ke atas pallet.

c. Postur kerja berdiri dengan posisi kaki menumpu pada conveyor dan pallet pada elemen kegiatan akan mengangkat produk jerigen $24 \mathrm{~kg}$ pada saat posisi tumpukan sudah banyak.

d. Postur kerja membungkuk dengan posisi kaki menumpu pada conveyor dan pallet serta tangan terlentang pada elemen kegiatan mengangkat produk kemasan jerigen $24 \mathrm{~kg}$ pada saat posisi tumpukan sudah banyak.

e. Postur kerja membungkuk dengan posisi kaki menumpu pada conveyor dan pallet serta tangan terlentang pada elemen kegiatan mengangkat produk kemasan jerigen $24 \mathrm{~kg}$ pada saat posisi tumpukan sudah banyak.

\section{Hasil dan Pembahasan}

Operator yang bekerja dibagian ini melakukan pekerjaan mengangkat produk sambal kemasan jerigen dengan berat $24 \mathrm{~kg}$ secara manual. Pekerjaan dilakukan secara terus menerus sesuai dengan target yang diinginkan perusahaan, selain itu operator juga harus menysusun produk sambal kemasan jerigen tersebut keatas sebuah pallet yang akan diangkat oleh forklift. 
Tabel 1. Metode Kerja Operator saat Mengangkat dan Menyusun Produk

\begin{tabular}{|c|c|c|c|}
\hline No & Elemen Kerja & Waktu (detik) & Sikap Kerja \\
\hline 1 & $\begin{array}{l}\text { Menunggu di atas conveyor sampai ke ujung tempat } \\
\text { pengangkatan }\end{array}$ & 5 & Berdiri \\
\hline 2 & $\begin{array}{l}\text { Mengangkat produk kemasan jerigen dengan berat } 24 \mathrm{~kg} \text { dari } \\
\text { conveyor ke atas sebuah pallet }\end{array}$ & 5 & $\begin{array}{l}\text { Berdiri dengan beban } 24 \mathrm{~kg} \text { dan } \\
\text { posisi tangan menekuk }\end{array}$ \\
\hline 3 & Meletakkan produk kemasan jerigen ke atas sebuah pallet & 6 & $\begin{array}{l}\text { Membungkuk dengan kemiringan } \\
45 \text { derajat, pergelanggan lurus } \\
\text { meletakkan produk kemasan jerigen } \\
\text { ke pallet }\end{array}$ \\
\hline
\end{tabular}

Postur kerja pegawai bagian palletizing. Data waktu postur kerja diambil secara acak sebanyak 5 buah dari setiap postur kerja yang dilakukan operator. Tujuan pengambilan data waktu postur kerja adalah untuk menganalisis pengaruh lamanya operator melakukan suatu postur kerja terhadap keluhan rasa sakit yang mungkin timbul pada bagian tubuh operator akibat postur kerja tersebut. Waktu dihitung mulai dari menunggu datangnya produk kemasan jerigen sampai operator mengangkat dan menyimpan produk kemasan jerigen ke atas palet. Adapun data waktu postur kerja, sebagai berikut:

Tabel 2. Postur Kerja pada saat Bekerja di Bagian Palletizing Line D

\begin{tabular}{|c|c|c|c|}
\hline No & Postur Kerja & Waktu (detik) & Keterangan \\
\hline & & 4 & $\begin{array}{l}\text { Posisi kerja pada saat mengambil } \\
\text { produk kemasan jerigen }\end{array}$ \\
\hline 1 & Berdiri dengan tangan terlentang & 3 & $\begin{array}{l}\text { Mengangkat produk kemasan } \\
\text { jerigen }\end{array}$ \\
\hline 2 & Berdiri dengan tangan terlentang dan posisi badan membungkuk & 5 & $\begin{array}{l}\text { Posisi kerja menyimpan produk } \\
\text { kemasan jerigen ke atas pallet } \\
\text { (kondisi tumpukan masih di bawah) }\end{array}$ \\
\hline 3 & Posisi badan berdiri dengan kaki mengangkang & 3 & $\begin{array}{l}\text { Posisi kerja pengambilan produk } \\
\text { kemasan jerigen pada saat tumpukan } \\
\text { mulai tinggi }\end{array}$ \\
\hline 4 & $\begin{array}{l}\text { Posisi badan berdiri dengan kaki mengangkang, sedikit } \\
\text { membungkuk dengan tangan terlentang mengambil jerigen }\end{array}$ & 5 & $\begin{array}{l}\text { Posisi kerja mengambil produk } \\
\text { kemasan jerigen di atas conveyor } \\
\text { (kondisi tumpukan jerigen sudah } \\
\text { tinggi) }\end{array}$ \\
\hline 5 & $\begin{array}{l}\text { Posisi badan berdiri dengan kaki mengangkang dari } \\
\text { membungkuk serta tangan yang terlentang meletakkan jerigen di } \\
\text { atas tumpukan }\end{array}$ & 6 & $\begin{array}{l}\text { Mengangkat produk kemasan } \\
\text { jerigen dan menyimpan ke atas } \\
\text { pallet dengan tumpukan yang sudah } \\
\text { tinggi }\end{array}$ \\
\hline
\end{tabular}

Fasilitas yang ada di bagian packing line $\mathrm{D}$ ini adalah conveyor dan pallet untuk menyimpan jerigen. Adapun tinggi conveyor sisi belakang $85 \mathrm{~cm}$ dan depan $54 \mathrm{~cm}$, panjang $408 \mathrm{~cm}$, serta lebar $50 \mathrm{~cm}$, conveyor ini berfungsi sebagai lintasan jerigen yang berjalan dari proses pengisian sambal yang kemudian siap diangkat ke atas pallet. Sementara itu, ukuran palet dengan panjang $100 \mathrm{~cm}$, lebar $120 \mathrm{~cm}$ dan tingginya $15 \mathrm{~cm}$ berfungsi untuk tempat penyimpanan jerigen sebelum di distribusikan ke konsumen. Dalam sekali sisi penuh terdapat 16 jerigen dengan berat $24 \mathrm{~kg}$, sehingga total berat adalah $384 \mathrm{~kg}$. Adapun data pebagai yang bekerja id bagian packing line $\mathrm{D}$ ini adalah sebagai beikut:

Tabel 3. Data Pegawai

\begin{tabular}{clcccc}
\hline No & Nama & Jenis Kelamin & Tinggi Tubuh & Umur & Lama Bekerja \\
\hline 1 & Eman Sulaeman & Laki-Laki & 168 & 27 & 6 Tahun \\
2 & Dedi Ruskandi & Laki-Laki & 170 & 24 & 5 Tahun \\
3 & Yudi Hermawan & Laki-Laki & 168 & 30 & 8 Tahun \\
\hline
\end{tabular}

Standard nordic questionaire dibuat untuk mengetahui keluhan yang dialami operator selama melaksanakan aktivitas penyusunan produk kemasan jerigen. Standard nordic questionaire memuat 27 keluhan sakit pada seluruh bagian tubuh. Standard nordic questionaire disebarkan pada hari kamis, 17 Oktober 2017 dengan metode memberi form questionaire ke operator yang bekerja pada bagian palletizing line D yang kemudian diisi. Adapun hasilnya disajikan pada tabel 4. 
Tabel 4. Hasil Standard Nordic Questionaire

\begin{tabular}{lll}
\hline No & Nama & \\
\hline & & Sakit kaku di leher bagian atas \\
& Partisipan 1 & Sakit di punggung \\
& & Sakit di pinggang \\
& Sakit kaku di leher bagian atas \\
& Sakit di punggung \\
& Sakit di pinggang \\
& Sakit pada bahu kiri \\
& Sakit pada lengan kanan \\
& Sakit kaku di leher bagian atas \\
& Sakit di punggung \\
& Sakit di pinggang \\
& & Sakit pada bahu kiri \\
& Sakit pada lengan kanan \\
& Partisipan 3 & Sakit pada kedua lutut \\
\hline
\end{tabular}

Hasil Standard Nordic Questionare yang telah diperoleh melalui wawancara langsung terhadap tiga operator yang telah bekerja minimal empat tahun pada bagian palletizing. Hasil tersebut menunjukkan bahwa keluhan yang paling banyak dirasakan oleh operator akibat postur kerja berdiri, membungkuk, berdiri dengan kaki mengangkang (Pangabean, 2009) adalah:

a. Sakit kaku dileher bagian atas dirasakan oleh dua orang operator atau dengan presentasi $67 \%$. Rasa sakit kaku di leher bagian atas sering dirasakan para pekerja apabila melakukan postur kerja membungkuk. Pada postur kerja tersebut, umumnya leher bagian atas operator berada pada posisi sangat menunduk untuk menyimpan produk kemasan jerigen.

b. Sakit kaku dibahu kanan yang dirasakan oleh satu orang operator atau dengan presentase 33\%. Rasa sakit kaku di bahu kanan dirasakan terutama apabila terjadi perubahan postur kerja dari postur kerja berdiri dengan tangan terlentang. Rasa sakit tersebut juga sangat terasa apabila operator melakukan postur kerja berdiri dengan tangan terlentang dalam waktu yang cukup lama.

c. Sakit di punggung yang dirasakan oleh tiga orang atau dengan presentase $100 \%$. Rasa sakit pada punggung lebih banyak dirasakan untuk postur kerja berdiri mengangkang dengan mengangkat produk kemasan jerigen, terutama bila dilakukan dalam waktu yang lama.

d. Sakit di punggung yang dirasakan oleh tiga operator atau dengan presentase $100 \%$. Rasa sakit dipinggang dikeluhkan oleh operator untuk ketiga jenis postur kerja, karena apabila ketiga jenis postur kerja dilakukan dalam waktu yang lama, rasa sakit dipinggang sangat terasa.

e. Sakit pada bahu kiri yang dirasakan oleh dua operator dengan presntase $67 \%$. Rasa sakit pada bahu kiri umumnya dirasakan oleh operator apabila melakukan postur kerja berdiri dengan tangan terlentang dalam waktu yang cukup lama.

f. Sakit pada lengan kanan yang dirasakan oleh operator atau dengan presentase $67 \%$. Rasa sakit pada lengan kanan dirasakan operator pada saat mengangkat produk kemasan jerigen keatas pallet.

g. Sakit pada kedua lutut yang dirasakan oleh satu operator atau dengan presentase 33\%. Rasa sakit pada kedua lutut dirasakan operator apabila melakukan postur kerja berdiri mengangkang dan membungkuk serta tangan yang terlentang meletakkan kemasan jerigen keatas pallet.

Berdasarkan hasil standard nordic questionare, keluhan rasa sakit pada bagian palleting dipengaruhi oleh beberapa faktor (Tarwaka \& Sudiajeng, 2004), antara lain:

a. Umur, faktor umur operator juga sangat memperngaruhi keluhan rasa sakit yang dirasakan dalam melaksanakan aktivitasnya. Berdasarkan hasil standard nordic questionaire, operator yang berumur 27 tahun lebih banyak mengalami rasa sakit pada bagian tubuhnya dibandingkan dengan pegawai yang berumur dibawah 27.

b. Lama Bekerja, pada umumnya operator yang bekerja lebih dari 6 tahun lebih banyak mengalami rasa sakit pada bagian tubuhnya dibandingkan dengan operator yang bekerja kurang dari 6 tahun.

Dari penelitian yang dilakukan maka dilakukan penilian sesuai dengan postur kerja yang dilakukan (Santoso, 2004), berikut:

a. Penilaian Postur Kerja, operator pada bagian kanan dan kiri tubuh operator pada saat mengangkat produk kemasan jerigen dengan postur berdiri berada posisi yang sama, sehingga perhitungan skor untuk postur kerja cukup dilakukan satu kali saja.

1.) Postur tubuh grup $A$ :

a.) Postur tubuh bagian lengan atas (upper arm). Lengan atas membentuk sudut $<90^{\circ}$ diberi skor $=2$. 
b.) Postur tubuh bagian lengan bawah (lower arm). Lengan bawah membentuk sudut $>100^{\circ}$, skor $=2$.

c.) Postur tubuh bagian pergelangan tangan (wrist). Sudut pergelangan tangan 0-150 diberi skor $=2$.

d.) Putaran pergelangan tangan (wrist twist). Putaran pegelangan tangan berada di garis tengah dengan skor $=1$.

Tabel 5. Grup A untuk Postur Berdiri

\begin{tabular}{|c|c|c|c|c|c|c|c|c|c|}
\hline \multirow{4}{*}{$\begin{array}{c}\text { Upper } \\
\text { Arm }\end{array}$} & \multirow{4}{*}{$\begin{array}{l}\text { Lower } \\
\text { Arm }\end{array}$} & \multicolumn{8}{|c|}{ Wrist } \\
\hline & & \multirow{2}{*}{\multicolumn{2}{|c|}{$\begin{array}{c}1 \\
\text { Wrist Twist }\end{array}$}} & & & \multirow{2}{*}{\multicolumn{2}{|c|}{$\begin{array}{c}3 \\
\text { Wrist Twist }\end{array}$}} & \multirow{2}{*}{\multicolumn{2}{|c|}{$\begin{array}{c}4 \\
\text { Wrist Twist }\end{array}$}} \\
\hline & & & & & & & & & \\
\hline & & 1 & 2 & (1) & 2 & 1 & 2 & 1 & 2 \\
\hline \multirow{3}{*}{1} & 1 & 1 & 2 & 2 & 2 & 2 & 3 & 3 & 3 \\
\hline & 2 & 2 & 2 & 2 & 2 & 3 & 3 & 3 & 3 \\
\hline & 3 & 2 & 3 & 2 & 3 & 3 & 3 & 4 & 4 \\
\hline \multirow{3}{*}{ (2) } & & 2 & 2 & 2 & 3 & 3 & 3 & 4 & 4 \\
\hline & (2) & 3 & 3 & (3) & 3 & 3 & 3 & 4 & 4 \\
\hline & 3 & 2 & 3 & 3 & 3 & 3 & 4 & 4 & 5 \\
\hline \multirow{3}{*}{3} & 1 & 2 & 3 & 3 & 3 & 4 & 4 & 5 & 5 \\
\hline & 2 & 2 & 3 & 3 & 3 & 4 & 4 & 5 & 5 \\
\hline & 3 & 2 & 3 & 3 & 4 & 4 & 4 & 5 & 5 \\
\hline \multirow{3}{*}{4} & 1 & 3 & 4 & 4 & 4 & 4 & 4 & 5 & 5 \\
\hline & 2 & 3 & 4 & 4 & 4 & 4 & 4 & 5 & 5 \\
\hline & 3 & 3 & 4 & 4 & 5 & 5 & 5 & 6 & 6 \\
\hline \multirow{3}{*}{5} & 1 & 5 & 5 & 5 & 5 & 5 & 6 & 6 & 7 \\
\hline & 2 & 5 & 6 & 6 & 6 & 6 & 7 & 7 & 7 \\
\hline & 3 & 6 & 6 & 6 & 7 & 7 & 7 & 7 & 8 \\
\hline \multirow{3}{*}{6} & 1 & 7 & 7 & 7 & 7 & 7 & 8 & 8 & 8 \\
\hline & 2 & 7 & 8 & 8 & 8 & 8 & 9 & 9 & 9 \\
\hline & 3 & 9 & 9 & 9 & 9 & 9 & 9 & 9 & 9 \\
\hline
\end{tabular}

a.) Skor postur kerja grup A berdasarkan tabel 5. di atas adalah 2.

b.) Skor aktivitas. Aktivitas dilakukan berulang-ulang, lebih dari 4 kali/menit dengan skor $=1$.

c.) Skor beban. Beban $>10 \mathrm{~kg}$ dengan skor $=3$.

d.) Total skor untuk grup A adalah $3+1+3=7$.

2.) Postur tubuh grup $B$ :

a.) Postur tubuh bagian leher (neck). Leher membentuk sudut $<10^{\circ}$ diberi skor $=1$.

b.) Postur tubuh bagian batang tubuh (trunk). Batang tubuh membentuk sudut $90^{\circ} /$ Normal diberi skor $1+1=2$.

c.) Postur tubuh dibagian kaki (legs). Kaki tidak seimbang dengan skor $=1$.

Tabel 6. Grup B untuk Postur Berdiri

\begin{tabular}{|c|c|c|c|c|c|c|c|c|c|c|c|c|}
\hline \multirow{4}{*}{ Neck } & \multicolumn{12}{|c|}{ Trunk } \\
\hline & \multicolumn{2}{|c|}{1} & \multirow{2}{*}{\multicolumn{2}{|c|}{$\begin{array}{c}\text { (2) } \\
\text { Legs }\end{array}$}} & \multirow{2}{*}{\multicolumn{2}{|c|}{$\begin{array}{c}3 \\
\text { Legs }\end{array}$}} & \multirow{2}{*}{\multicolumn{2}{|c|}{$\begin{array}{c}4 \\
\text { Legs }\end{array}$}} & \multirow{2}{*}{\multicolumn{2}{|c|}{$\begin{array}{c}5 \\
\text { Legs }\end{array}$}} & \multirow{2}{*}{\multicolumn{2}{|c|}{$\begin{array}{c}6 \\
\text { Legs }\end{array}$}} \\
\hline & \multicolumn{2}{|c|}{ Legs } & & & & & & & & & & \\
\hline & 1 & 2 & (1) & 2 & 1 & 2 & 1 & 2 & 1 & 2 & 1 & 2 \\
\hline 1 & 1 & 3 & (2) & 3 & 3 & 4 & 5 & 5 & 6 & 6 & 7 & 7 \\
\hline (2) & 2 & 3 & 2 & 3 & 4 & 5 & 5 & 5 & 6 & 7 & 7 & 7 \\
\hline 3 & 3 & 3 & 3 & 4 & 4 & 5 & 5 & 6 & 6 & 7 & 7 & 7 \\
\hline 4 & 5 & 5 & 5 & 6 & 6 & 7 & 7 & 7 & 7 & 7 & 8 & 8 \\
\hline 5 & 7 & 7 & 7 & 7 & 7 & 8 & 8 & 8 & 8 & 8 & 8 & 8 \\
\hline 6 & 8 & 8 & 8 & 8 & 8 & 8 & 8 & 9 & 9 & 9 & 9 & 9 \\
\hline
\end{tabular}

a.) Skor postur tubuh grup B berdasarkan tabel 6. di atas adalah $=2$.

b.) Skor aktivitas. Aktivitas dilakukan berulang-ulang, lebih dari 4 kali/menit dengan skor $=1$.

c.) Skor beban. Beban $>10 \mathrm{~kg}$ dengan skor $=3$.

d.) Total skor untuk grup A adalah $2+1+3=6$.

3.) Skor akhir dapat dilihat pada tabel 7. di bawah ini. 
Tabel 7. Skor Grup C Postur Kerja Berdiri

\begin{tabular}{clllclll}
\hline $\begin{array}{c}\text { Skor } \\
\text { Grup A }\end{array}$ & 1 & 2 & 3 & Skor Grup B & 5 & 7 \\
\hline 1 & 1 & 2 & 3 & 3 & 4 & 5 & 5 \\
2 & 2 & 2 & 3 & 4 & 4 & 5 & 5 \\
3 & 3 & 3 & 3 & 4 & 4 & 5 & 6 \\
4 & 3 & 3 & 3 & 4 & 5 & 6 & 6 \\
5 & 4 & 4 & 4 & 5 & 6 & 7 & 7 \\
6 & 4 & 4 & 5 & 6 & 6 & 7 & 7 \\
7 & 5 & 5 & 6 & 6 & 7 & 7 & 7 \\
8 & 5 & 5 & 6 & 7 & 7 & 7 & 7 \\
\hline
\end{tabular}

Skor akhir untuk aktivitas berdiri memegang dan mengangkat produk kemasan jerigen 24 $\mathrm{kg}$ berdasarkan tabel 7. di atas adalah 7. Berdasarkan skor tersebut maka level resiko dari aktivitas ini berada pada kategori level resiko tinggi dan diperluka juga tindakan perbaikan postur kerja sekarang juga. Dari penjelasan tersebut, dapat dilihat secara ringkas gambar 1. RULA employee assesment worksheet di bawah ini.

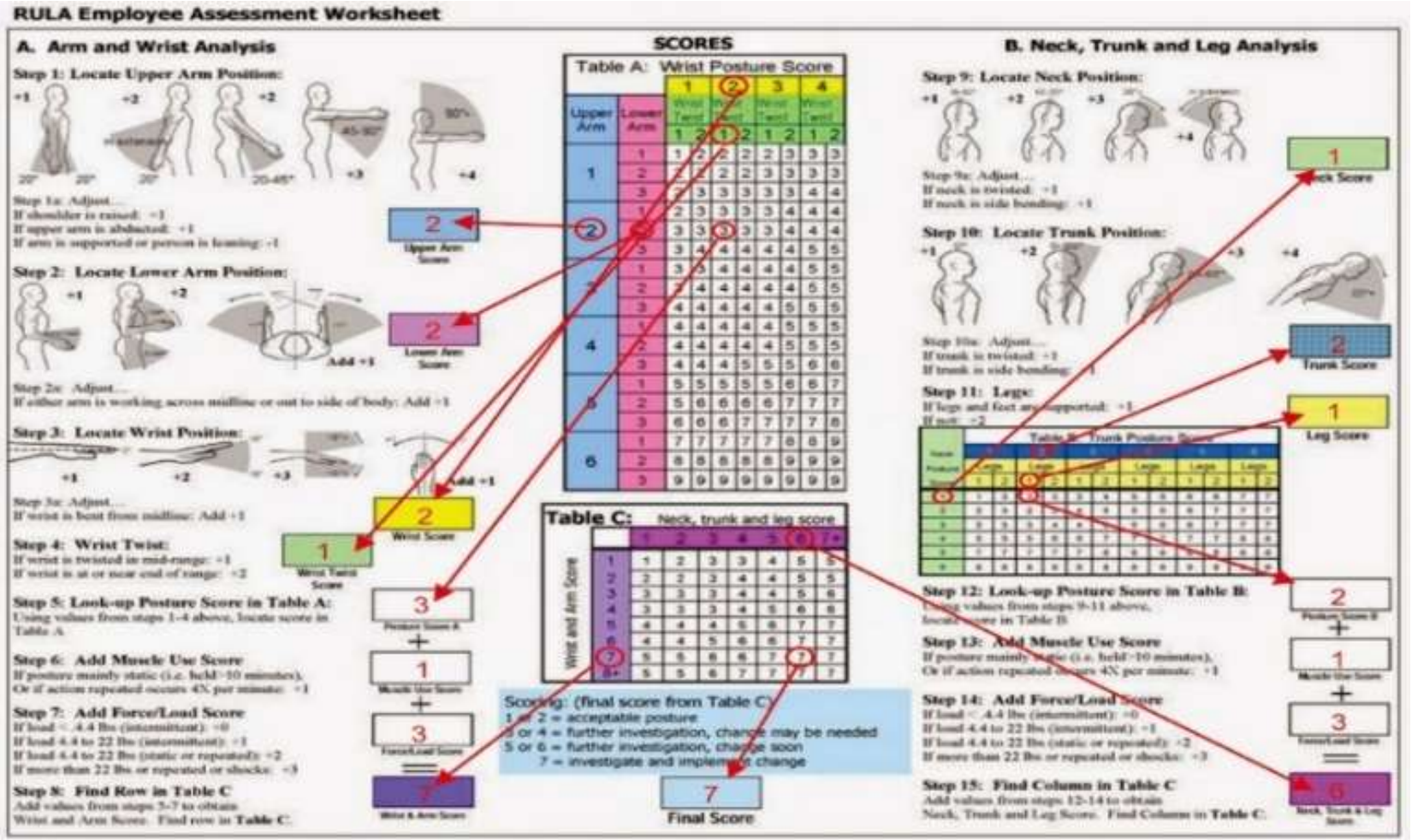

Gambar 1. RULA Employee Assesment Worksheet

b. Penilaian Postur Kerja, posisi kerja dalam keadaan membungkuk dan kondisi berdiri ini mengakibatkan postur kurang baik. Oleh karena itu butuh perbaikan, berikut proses skor dengan metode RULA.

1.) Postur tubuh grup $A$ :

a.) Postur tubuh bagian lengan atas (upper arm). Lengan atas membentuk sudut $<90^{\circ}$ diberi skor $2+$ $1=3$.

b.) Postur tubuh bagian lengan bawah (lower arm). Lengan bawah membentuk sudut $>100^{\circ}$, skor $=2$.

c.) Postur tubuh bagian pergelangan tangan (wrist). Sudut pergelangan tangan $>15^{\circ}$ diberi skor $=3$.

d.) Putaran pergelangan tangan (wrist twist). Putaran pegelangan tangan berada di garis tengah dengan skor $=1$. 
Tabel 8. Grup A untuk Postur Berdiri dengan Membungkuk

\begin{tabular}{|c|c|c|c|c|c|c|c|c|c|}
\hline \multirow{4}{*}{$\begin{array}{c}\text { Upper } \\
\text { Arm }\end{array}$} & \multirow{4}{*}{$\begin{array}{c}\text { Lower } \\
\text { Arm }\end{array}$} & \multicolumn{8}{|c|}{ Wrist } \\
\hline & & \multicolumn{2}{|c|}{1} & \multicolumn{2}{|c|}{2} & \multirow{2}{*}{\multicolumn{2}{|c|}{ Wrist Twist }} & \multicolumn{2}{|c|}{4} \\
\hline & & \multicolumn{2}{|c|}{ Wrist Twist } & \multicolumn{2}{|c|}{ Wrist Twist } & & & \multicolumn{2}{|c|}{ Wrist Twist } \\
\hline & & 1 & 2 & 1 & 2 & & 2 & 1 & 2 \\
\hline \multirow{3}{*}{1} & 1 & 1 & 2 & 2 & 2 & 2 & 3 & 3 & 3 \\
\hline & 2 & 2 & 2 & 2 & 2 & 3 & 3 & 3 & 3 \\
\hline & 3 & 2 & 3 & 2 & 3 & 3 & 3 & 4 & 4 \\
\hline \multirow{3}{*}{2} & 1 & 2 & 2 & 2 & 3 & 3 & 3 & 4 & 4 \\
\hline & 2 & 3 & 3 & 3 & 3 & 3 & 3 & 4 & 4 \\
\hline & 3 & 2 & 3 & 2 & 3 & 3 & 3 & 4 & 4 \\
\hline \multirow{6}{*}{4} & & 2 & 3 & 3 & 3 & 4 & 4 & 5 & 5 \\
\hline & & 2 & 3 & 3 & 3 & 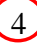 & 4 & 5 & 5 \\
\hline & 3 & 2 & 3 & 3 & 4 & 4 & 4 & 5 & 5 \\
\hline & 1 & 3 & 4 & 4 & 4 & 4 & 4 & 5 & 5 \\
\hline & 2 & 3 & 4 & 4 & 4 & 4 & 4 & 5 & 5 \\
\hline & 3 & 3 & 4 & 4 & 5 & 5 & 5 & 6 & 6 \\
\hline \multirow{3}{*}{5} & 1 & 5 & 5 & 5 & 5 & 5 & 6 & 6 & 7 \\
\hline & 2 & 5 & 6 & 6 & 6 & 6 & 7 & 7 & 7 \\
\hline & 3 & 6 & 6 & 6 & 7 & 7 & 7 & 7 & 8 \\
\hline \multirow{3}{*}{6} & 1 & 7 & 7 & 7 & 7 & 7 & 8 & 8 & 9 \\
\hline & 2 & 7 & 8 & 8 & 8 & 8 & 9 & 9 & 9 \\
\hline & 3 & 9 & 9 & 9 & 9 & 9 & 9 & 9 & 9 \\
\hline
\end{tabular}

a.) Skor postur kerja grup A berdasarkan tabel 8. di atas adalah 4 .

b.) Skor aktivitas. Aktivitas dilakukan berulang-ulang, lebih dari $4 \mathrm{kali} / \mathrm{menit}$ dengan $\mathrm{skor}=1$.

c.) Skor beban. Beban $>10 \mathrm{~kg}$ dengan skor $=3$.

d.) Total skor untuk grup A adalah $4+1+3=8$.

2.) Postur tubuh grup $B$ :

a.) Postur tubuh bagian leher (neck). Leher membentuk sudut, $10^{\circ}-20^{\circ}$ diberi skor $=2$.

b.) Postur tubuh bagian batang tubuh (trunk). Batang tubuh membentuk sudut $20^{\circ}-60^{\circ}$ diberi skor $=$ 3.

c.) Postur tubuh dibagian kaki (legs). Kaki tidak seimbang dengan skor $=1$.

Tabel 9. Grup B untuk Postur Berdiri dengan Membungkuk

\begin{tabular}{|c|c|c|c|c|c|c|c|c|c|c|c|c|}
\hline \multirow{4}{*}{ Neck } & \multicolumn{12}{|c|}{ Trunk } \\
\hline & \multirow{2}{*}{\multicolumn{2}{|c|}{$\begin{array}{c}1 \\
\text { Legs }\end{array}$}} & \multirow{2}{*}{\multicolumn{2}{|c|}{$\begin{array}{c}2 \\
\text { Legs }\end{array}$}} & \multirow{2}{*}{\multicolumn{2}{|c|}{$\begin{array}{c}\text { (3) } \\
\text { Legs }\end{array}$}} & \multirow{2}{*}{\multicolumn{2}{|c|}{$\begin{array}{c}4 \\
\text { Legs }\end{array}$}} & \multirow{2}{*}{\multicolumn{2}{|c|}{$\begin{array}{c}5 \\
\text { Legs }\end{array}$}} & \multirow{2}{*}{\multicolumn{2}{|c|}{$\begin{array}{c}6 \\
\text { Legs }\end{array}$}} \\
\hline & & & & & & & & & & & & \\
\hline & 1 & 2 & 1 & 2 & (1) & 2 & 1 & 2 & 1 & 2 & 1 & 2 \\
\hline 1 & 1 & 3 & 2 & 3 & 3 & 4 & 5 & 5 & 6 & 6 & 7 & 7 \\
\hline (2) & 2 & 3 & 2 & 3 & (4) & 5 & 5 & 5 & 6 & 7 & 7 & 7 \\
\hline 3 & 3 & 3 & 3 & 4 & 4 & 5 & 5 & 6 & 6 & 7 & 7 & 7 \\
\hline 4 & 5 & 5 & 5 & 6 & 6 & 7 & 7 & 7 & 7 & 7 & 8 & 8 \\
\hline 5 & 7 & 7 & 7 & 7 & 7 & 8 & 8 & 8 & 8 & 8 & 8 & 8 \\
\hline 6 & 8 & 8 & 8 & 8 & 8 & 8 & 8 & 9 & 9 & 9 & 9 & 9 \\
\hline
\end{tabular}

a.) Skor postur tubuh grup B berdasarkan tabel 9. di atas adalah $=4$.

b.) Skor aktivitas. Aktivitas dilakukan berulang-ulang, lebih dari 4 kali/menit dengan skor $=1$.

c.) Skor beban. Beban $>10 \mathrm{~kg}$ dengan skor $=3$.

d.) Total skor untuk grup A adalah $4+1+3=8$.

3.) Skor akhir dapat dilihat pada tabel 10. di bawah ini.

Tabel 10. Skor Grup C Postur Kerja Berdiri dengan Membungkuk

\begin{tabular}{cccccccc}
\hline $\begin{array}{c}\text { Skor } \\
\text { Grup A }\end{array}$ & 1 & 2 & 3 & 4 & 5 & 6 & 7 \\
\hline 1 & 1 & 2 & 3 & 3 & 4 & 5 & 5 \\
2 & 2 & 2 & 3 & 4 & 4 & 5 & 5 \\
3 & 3 & 3 & 3 & 4 & 4 & 5 & 6 \\
4 & 3 & 3 & 3 & 4 & 5 & 6 & 6 \\
5 & 4 & 4 & 4 & 5 & 6 & 7 & 7 \\
6 & 5 & 5 & 6 & 6 & 7 & 7 & 7 \\
$7+$ & 5 & 6 & 6 & 7 & 7 & 7 & 7 \\
\hline
\end{tabular}


Skor akhir untuk aktivitas berdiri dengan membungkuk dan meletakkan produk kemasan jerigen berdasarkan tabel X adalah 7. Berdasarkan skor tersebut, maka resiko dari aktivitas ini berada pada kategori level resiko tinggi dan diperlukan tindakan perbaikan postur kerja sekarang juga. Dari penjelasan ditersebut dapat dilihat secara ringkas pada gambar 2. RULA employee assesment worksheet di bawah ini.

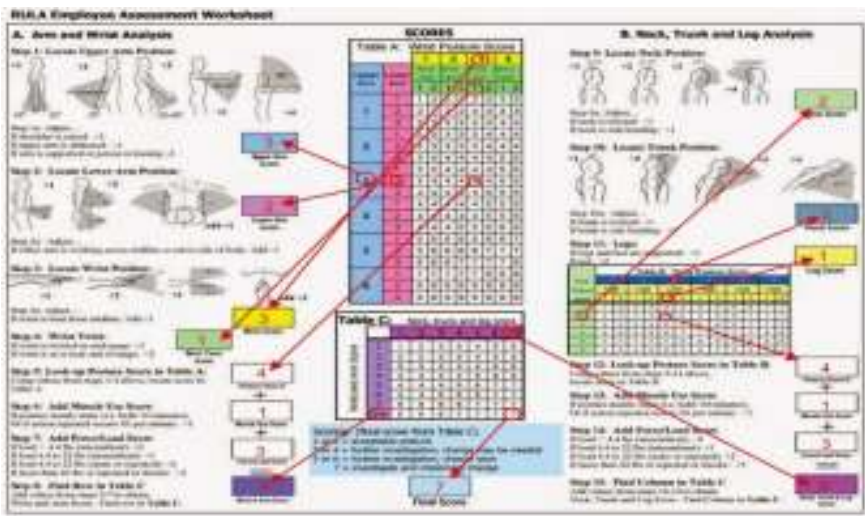

Gambar 2. RULA Employee Assesment Worksheet

c. Penilaian Postur Kerja

1.) Postur tubuh grup $A$ :

a.) Postur tubuh bagian lengan atas (upper arm). Lengan atas membentuk sudut $<90^{\circ}$ diberi skor $=2$.

b.) Postur tubuh bagian lengan bawah (lower arm). Lengan bawah membentuk sudut $<100^{\circ}$, skor $=1$.

c.) Postur tubuh bagian pergelangan tangan (wrist). Sudut pergelangan tangan $<15^{\circ}$ diberi skor $=1$.

d.) Putaran pergelangan tangan (wrist twist). Putaran pegelangan tangan berada di garis tengh dengan skor $=1$.

Tabel 11. Grup A untuk Postur Berdiri Mengangkang

\begin{tabular}{|c|c|c|c|c|c|c|c|c|c|}
\hline \multirow{4}{*}{$\begin{array}{l}\text { Upper } \\
\text { Arm }\end{array}$} & \multirow{4}{*}{$\begin{array}{l}\text { Lower } \\
\text { Arm }\end{array}$} & \multicolumn{8}{|c|}{ Wrist } \\
\hline & & & & \multicolumn{2}{|c|}{2} & \multirow{2}{*}{\multicolumn{2}{|c|}{$\begin{array}{c}3 \\
\text { Wrist Twist }\end{array}$}} & \multirow{2}{*}{\multicolumn{2}{|c|}{$\begin{array}{c}4 \\
\text { Wrist Twist }\end{array}$}} \\
\hline & & & & & & & & & \\
\hline & & & 2 & 1 & 2 & 1 & 2 & 1 & 2 \\
\hline \multirow{3}{*}{1} & 1 & 1 & 2 & 2 & 2 & 2 & 3 & 3 & 3 \\
\hline & 2 & 2 & 2 & 2 & 2 & 3 & 3 & 3 & 3 \\
\hline & 3 & 2 & 3 & 2 & 3 & 3 & 3 & 4 & 4 \\
\hline \multirow{3}{*}{ (2) } & (1) & $2)$ & 2 & 2 & 3 & 3 & 3 & 4 & 4 \\
\hline & 2 & 3 & 3 & 3 & 3 & 3 & 3 & 4 & 4 \\
\hline & 3 & 2 & 3 & 3 & 3 & 3 & 4 & 4 & 5 \\
\hline \multirow{3}{*}{3} & 1 & 2 & 3 & 3 & 3 & 4 & 4 & 5 & 5 \\
\hline & 2 & 2 & 3 & 3 & 3 & 4 & 4 & 5 & 5 \\
\hline & 3 & 2 & 3 & 3 & 4 & 4 & 4 & 5 & 5 \\
\hline \multirow{3}{*}{4} & 1 & 3 & 4 & 4 & 4 & 4 & 4 & 5 & 5 \\
\hline & 2 & 3 & 4 & 4 & 4 & 4 & 4 & 5 & 5 \\
\hline & 3 & 3 & 4 & 4 & 5 & 5 & 5 & 6 & 6 \\
\hline \multirow{3}{*}{5} & 1 & 5 & 5 & 5 & 5 & 5 & 6 & 6 & 7 \\
\hline & 2 & 5 & 6 & 6 & 6 & 6 & 7 & 7 & 7 \\
\hline & 3 & 6 & 6 & 6 & 7 & 7 & 7 & 7 & 8 \\
\hline \multirow{3}{*}{6} & 1 & 7 & 7 & 7 & 7 & 7 & 8 & 8 & 9 \\
\hline & 2 & 7 & 8 & 8 & 8 & 8 & 9 & 9 & 9 \\
\hline & 3 & 9 & 9 & 9 & 9 & 9 & 9 & 9 & 9 \\
\hline
\end{tabular}

a.) Skor postur kerja grup A berdasarkan tabel 11. di atas adalah 2 .

b.) Skor aktivitas. Aktivitas dilakukan berulang-ulang, lebih dari 4 kali/menit dengan skor $=1$.

c.) Skor beban. Beban $<2 \mathrm{~kg}$ dengan skor $=0$.

d.) Total skor untuk grup A adalah $2+1+0=3$. 
2.) Postur tubuh grup $B$ :

a.) Postur tubuh bagian leher (neck). Leher membentuk sudut $<10^{\circ}$ diberi skor $=1$.

b.) Postur tubuh bagian batang tubuh (trunk). Batang tubuh membentuk sudut $<20^{\circ}$ diberi skor $1+1=$ 2.

c.) Postur tubuh dibagian kaki (legs). Kaki tidak seimbang dengan skor $=2$.

Tabel 12. Grup B untuk Postur Berdiri Mengangkang

\begin{tabular}{|c|c|c|c|c|c|c|c|c|c|c|c|c|}
\hline \multirow{3}{*}{ Neck } & \multicolumn{12}{|c|}{ Trunk } \\
\hline & \multicolumn{2}{|c|}{$\begin{array}{c}1 \\
\text { Legs }\end{array}$} & \multicolumn{2}{|c|}{$\begin{array}{l}\text { (2) } \\
\text { Legs }\end{array}$} & \multicolumn{2}{|c|}{$\begin{array}{c}3 \\
\text { Legs }\end{array}$} & \multicolumn{2}{|c|}{$\begin{array}{c}4 \\
\text { Legs }\end{array}$} & \multicolumn{2}{|c|}{$\begin{array}{c}5 \\
\text { Legs }\end{array}$} & \multicolumn{2}{|c|}{$\begin{array}{c}6 \\
\text { Legs }\end{array}$} \\
\hline & 1 & 2 & 1 & (2) & 1 & 2 & 1 & 2 & 1 & 2 & 1 & 2 \\
\hline (1) & 1 & 3 & 2 & (3) & 3 & 4 & 5 & 5 & 6 & 6 & 7 & 7 \\
\hline 2 & 2 & 3 & 2 & 3 & 4 & 5 & 5 & 5 & 6 & 7 & 7 & 7 \\
\hline 3 & 3 & 3 & 3 & 4 & 4 & 5 & 5 & 6 & 6 & 7 & 7 & 7 \\
\hline 4 & 5 & 5 & 5 & 6 & 6 & 7 & 7 & 7 & 7 & 7 & 8 & 8 \\
\hline 5 & 7 & 7 & 7 & 7 & 7 & 8 & 8 & 8 & 8 & 8 & 8 & 8 \\
\hline 6 & 8 & 8 & 8 & 8 & 8 & 8 & 8 & 9 & 9 & 9 & 9 & 9 \\
\hline
\end{tabular}

a.) Skor aktivitas. Aktivitas dilakukan berulang-ulang, lebih dari 4 kali/menit dengan skor $=1$.

b.) Skor beban. Beban $<2 \mathrm{~kg}$ dengan skor $=0$.

c.) Total skor untuk grup A adalah $3+1=4$.

3.) Skor akhir dapat dilihat pada tabel 13. di bawah ini.

Tabel 13. Skor Grup C Postur Berdiri Mangangkang

\begin{tabular}{|c|c|c|c|c|c|c|c|}
\hline Skor & \multicolumn{7}{|c|}{ Skor Grup B } \\
\hline Grup A & 1 & 2 & 3 & (4) & 5 & 6 & 7 \\
\hline 1 & 1 & 2 & 3 & 3 & 4 & 5 & 5 \\
\hline 2 & 2 & 2 & 3 & 4 & 4 & 5 & 5 \\
\hline (3) & 3 & 3 & 3 & (4) & 4 & 5 & 6 \\
\hline 4 & 3 & 3 & 3 & 4 & 5 & 6 & 6 \\
\hline 5 & 4 & 4 & 4 & 5 & 6 & 7 & 7 \\
\hline 6 & 4 & 4 & 5 & 6 & 6 & 7 & 7 \\
\hline 7 & 5 & 5 & 6 & 6 & 7 & 7 & 7 \\
\hline 8 & 5 & 5 & 6 & 7 & 7 & 7 & 7 \\
\hline
\end{tabular}

Skor akhir untuk aktivitas berdiri dengan mengangkang berdasarkan Tabel 13. di atas adalah 4. Berdasarkan skor tersebut maka level resiko dari aktivitas ini berada pada kategori level resiko kecil dan diperlukan beberapa waktu kedepan. Dari penjelasan tersebut, dapat dilihat secara ringkas pada gambar 3. RULA employee assesment worksheet di bawah ini.

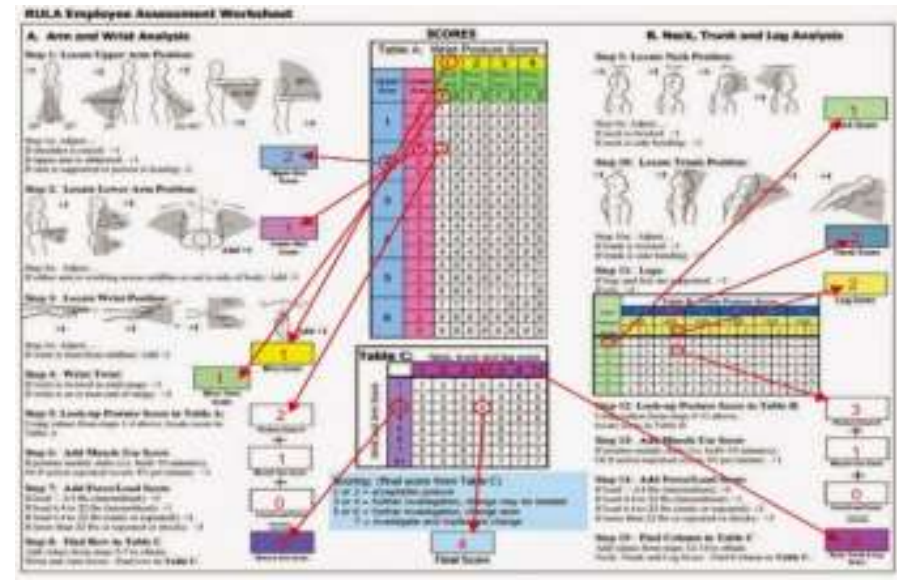

Gambar 3. RULA Employee Assesment Worksheet

d. Penilaian postur kerja berdiri sambil membungkuk. Perhitungan skor untuk postur kerja cukup dilakukan satu kali saja.

1.) Postur tubuh grup $A$ : 
a.) Postur tubuh bagian lengan atas (upper arm). Lengan atas membentuk sudut $45^{\circ}-90^{\circ}$ diberi skor $=$ 3.

b.) Postur tubuh bagian lengan bawah (lower arm). Lengan bawah membentuk sudut $<90^{\circ}$, skor $=1$.

c.) Postur tubuh bagian pergelangan tangan (wrist). Sudut pergelangan tangan $>15^{\circ}$ diberi skor $=2$.

d.) Putaran pergelangan tangan (wrist twist). Putaran pegelangan tangan berada di garis tengh dengan skor $=1$

Tabel 14. Grup A untuk Postur Berdiri Mengangkang Mengangkat Jerigen

\begin{tabular}{|c|c|c|c|c|c|c|c|c|c|}
\hline \multirow{4}{*}{$\begin{array}{l}\text { Upper } \\
\text { Arm }\end{array}$} & \multirow{4}{*}{$\begin{array}{l}\text { Lower } \\
\text { Arm }\end{array}$} & \multicolumn{8}{|c|}{ Wrist } \\
\hline & & \multirow{2}{*}{\multicolumn{2}{|c|}{$\begin{array}{c}1 \\
\text { Wrist Twist }\end{array}$}} & & & \multirow{2}{*}{\multicolumn{2}{|c|}{$\begin{array}{c}3 \\
\text { Wrist Twist }\end{array}$}} & \multirow{2}{*}{\multicolumn{2}{|c|}{$\begin{array}{c}4 \\
\text { Wrist Twist }\end{array}$}} \\
\hline & & & & & & & & & \\
\hline & & 1 & 2 & 1) & 2 & 1 & 2 & 1 & 2 \\
\hline \multirow{3}{*}{1} & 1 & 1 & 2 & 2 & 2 & 2 & 3 & 3 & 3 \\
\hline & 2 & 2 & 2 & 2 & 2 & 3 & 3 & 3 & 3 \\
\hline & 3 & 2 & 3 & 2 & 3 & 3 & 3 & 4 & 4 \\
\hline \multirow{3}{*}{2} & 1 & 2 & 2 & 2 & 3 & 3 & 3 & 4 & 4 \\
\hline & 2 & 3 & 3 & 3 & 3 & 3 & 3 & 4 & 4 \\
\hline & 3 & 2 & 3 & 3 & 3 & 3 & 4 & 4 & 5 \\
\hline \multirow{3}{*}{ (3) } & (1) & 2 & 3 & (4) & 4 & 4 & 4 & 5 & 5 \\
\hline & 2 & 2 & 3 & 3 & 3 & 4 & 4 & 5 & 5 \\
\hline & 3 & 2 & 3 & 3 & 4 & 4 & 4 & 5 & 5 \\
\hline \multirow{3}{*}{4} & 1 & 3 & 4 & 4 & 4 & 4 & 4 & 5 & 5 \\
\hline & 2 & 3 & 4 & 4 & 4 & 4 & 4 & 5 & 5 \\
\hline & 3 & 3 & 4 & 4 & 5 & 5 & 5 & 6 & 6 \\
\hline \multirow{3}{*}{5} & 1 & 5 & 5 & 5 & 5 & 5 & 6 & 6 & 7 \\
\hline & 2 & 5 & 6 & 6 & 6 & 6 & 7 & 7 & 7 \\
\hline & 3 & 6 & 6 & 6 & 7 & 7 & 7 & 7 & 8 \\
\hline \multirow{3}{*}{6} & 1 & 7 & 7 & 7 & 7 & 7 & 8 & 8 & 9 \\
\hline & 2 & 7 & 8 & 8 & 8 & 8 & 9 & 9 & 9 \\
\hline & 3 & 9 & 9 & 9 & 9 & 9 & 9 & 9 & 9 \\
\hline
\end{tabular}

a.) Skor postur kerja grup A berdasarkan tabel 14. di atas adalah 2.

e.) Skor aktivitas. Aktivitas dilakukan berulang-ulang, lebih dari 4 kali/menit dengan skor $=1$.

f.) Skor beban. Beban $>10 \mathrm{~kg}$ dengan skor $=3$.

g.) Total skor untuk grup A adalah $4+1+3=8$.

2.) Postur tubuh grup $B$ :

a.) Postur tubuh bagian leher (neck). Leher membentuk sudut $<10^{\circ}$ diberi skor $=1$

b.) Postur tubuh bagian batang tubuh (trunk). Batang tubuh membentuk sudut $20^{\circ}-60^{\circ}$ diberi skor $1+1$ $=2$.

c.) Postur tubuh dibagian kaki (legs). Kaki tidak seimbang dengan skor $=2$.

Tabel 15. Grup B untuk Postur Berdiri Mengangkang Mengangkat Jerigen

\begin{tabular}{|c|c|c|c|c|c|c|c|c|c|c|c|c|}
\hline \multirow{4}{*}{ Neck } & \multicolumn{12}{|c|}{ Trunk } \\
\hline & \multirow{2}{*}{\multicolumn{2}{|c|}{$\begin{array}{c}1 \\
\operatorname{Leg} S\end{array}$}} & \multirow{2}{*}{\multicolumn{2}{|c|}{$\begin{array}{l}\text { (2) } \\
\text { Legs }\end{array}$}} & \multirow{2}{*}{\multicolumn{2}{|c|}{$\begin{array}{c}3 \\
\text { Legs }\end{array}$}} & \multirow{2}{*}{\multicolumn{2}{|c|}{$\begin{array}{c}4 \\
\text { Legs }\end{array}$}} & \multirow{2}{*}{\multicolumn{2}{|c|}{$\begin{array}{c}5 \\
\text { Legs }\end{array}$}} & \multirow{2}{*}{\multicolumn{2}{|c|}{$\begin{array}{c}6 \\
\text { Legs }\end{array}$}} \\
\hline & & & & & & & & & & & & \\
\hline & 1 & 2 & 1 & (2) & 1 & 2 & 1 & 2 & 1 & 2 & 1 & 2 \\
\hline (1) & 1 & 3 & 2 & (3) & 3 & 4 & 5 & 5 & 6 & 6 & 7 & 7 \\
\hline 2 & 2 & 3 & 2 & 3 & 4 & 5 & 5 & 5 & 6 & 7 & 7 & 7 \\
\hline 3 & 3 & 3 & 3 & 4 & 4 & 5 & 5 & 6 & 6 & 7 & 7 & 7 \\
\hline 4 & 5 & 5 & 5 & 6 & 6 & 7 & 7 & 7 & 7 & 7 & 8 & 8 \\
\hline 5 & 7 & 7 & 7 & 7 & 7 & 8 & 8 & 8 & 8 & 8 & 8 & 8 \\
\hline 6 & 8 & 8 & 8 & 8 & 8 & 8 & 8 & 9 & 9 & 9 & 9 & 9 \\
\hline
\end{tabular}

a.) Skor postur tubuh grup B berdasarkan tabel 15. di atas adalah $=2$.

b.) Skor aktivitas. Aktivitas dilakukan berulang-ulang, lebih dari 4 kali/menit dengan skor $=1$.

c.) Skor beban. Beban $>10 \mathrm{~kg}$ dengan skor $=3$.

d.) Total skor untuk grup A adalah $3+1+3=7$.

3.) Skor akhir dapat dilihat pada tabel 16. di bawah ini. 
Tabel 16. Skor Grup C Postur Kerja Berdiri Mengangkang Mengangkat Jerigen

\begin{tabular}{cccccccccc}
\hline $\begin{array}{c}\text { Skor } \\
\text { Grup A }\end{array}$ & 1 & 2 & 3 & 4 & 5 & 6 & 7 & 8 & 9 \\
\hline 1 & 1 & 2 & 3 & 3 & 4 & 5 & 5 & 5 & 6 \\
2 & 2 & 2 & 3 & 4 & 4 & 5 & 5 & 6 & 6 \\
3 & 3 & 3 & 3 & 4 & 4 & 5 & 6 & 6 & 6 \\
4 & 3 & 3 & 3 & 4 & 5 & 6 & 6 & 6 & 7 \\
5 & 4 & 4 & 4 & 5 & 6 & 7 & 7 & 7 & 8 \\
6 & 4 & 4 & 5 & 6 & 6 & 7 & 7 & 7 & 8 \\
7 & 5 & 5 & 6 & 6 & 7 & 7 & 7 & 8 & 8 \\
$7+$ & 5 & 5 & 6 & 7 & 7 & 7 & 8 & 8 & 8 \\
\hline
\end{tabular}

Skor akhir untuk aktivitas berdiri mengangkang dengan posisi mengangkat beban jerigen $24 \mathrm{~kg}$ mendapatkan skor total sebesar 8 dengan resiko sangat tinggi dan perlu tindakan sekarang juga. Penjelasan tersebut dapat dilihat secara ringkas pada gambar 4. RULA employee assesment worksheet.

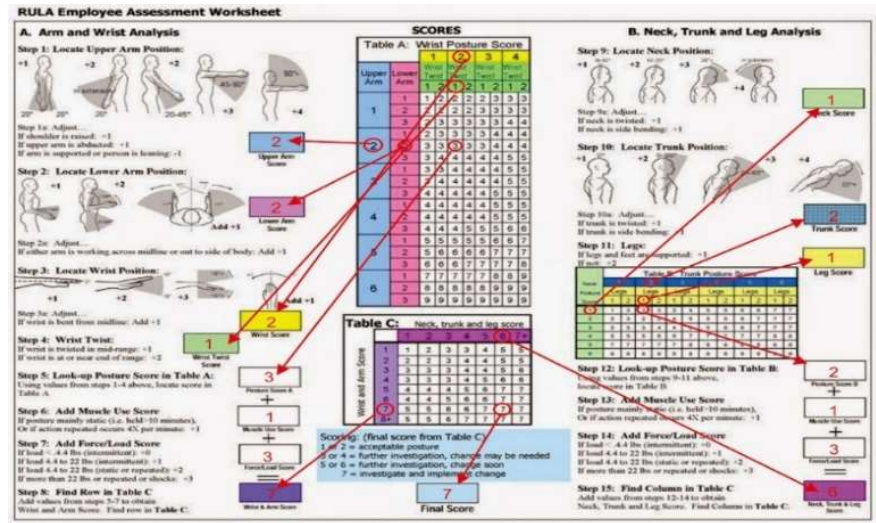

Gambar 4. RULA Employee Assesment Worksheet

e. Penilaian Postur Kerja berdiri menyimpan jerigen.

1.) Postur tubuh grup A:

a.) Postur tubuh bagian lengan atas (upper arm). Lengan atas membentuk sudut $<90^{\circ}$ diberi skor $=3$.

b.) Postur tubuh bagian lengan bawah (lower arm). Lengan bawah membentuk sudut $>100^{\circ}$, skor $=2$.

c.) Postur tubuh bagian pergelangan tangan (wrist). Sudut pergelangan tangan $<15^{\circ}$ diberi skor $=1$.

d.) Putaran pergelangan tangan (wrist twist). Putaran pegelangan tangan berada di garis tengh dengan skor $=1$.

Tabel 17. Grup A untuk Postur Berdiri Mengangkang Menyimpan Produk Kemasan Jerigen

\begin{tabular}{|c|c|c|c|c|c|c|c|c|c|}
\hline \multirow{4}{*}{$\begin{array}{c}\text { Upper } \\
\text { Arm }\end{array}$} & \multirow{4}{*}{$\begin{array}{c}\text { Lower } \\
\text { Arm }\end{array}$} & \multicolumn{8}{|c|}{ Wrist } \\
\hline & & & & \multicolumn{2}{|c|}{2} & \multirow{2}{*}{\multicolumn{2}{|c|}{$\begin{array}{c}3 \\
\text { Wrist Twist }\end{array}$}} & \multirow{2}{*}{\multicolumn{2}{|c|}{$\begin{array}{c}4 \\
\text { Wrist Twist }\end{array}$}} \\
\hline & & & & & & & & & \\
\hline & & & 2 & 1 & 2 & 1 & 2 & 1 & 2 \\
\hline \multirow{3}{*}{1} & 1 & 1 & 2 & 2 & 2 & 2 & 3 & 3 & 3 \\
\hline & 2 & 2 & 3 & 3 & 2 & 3 & 3 & 3 & 3 \\
\hline & 3 & 2 & 3 & 2 & 3 & 3 & 3 & 4 & 4 \\
\hline \multirow{3}{*}{2} & 1 & 2 & 2 & 2 & 3 & 3 & 3 & 4 & 4 \\
\hline & 2 & 2 & 3 & 3 & 3 & 3 & 3 & 4 & 4 \\
\hline & 3 & 2 & 3 & 3 & 3 & 3 & 4 & 4 & 5 \\
\hline \multirow{3}{*}{ (3) } & & & 3 & 3 & 3 & 4 & 4 & 5 & 5 \\
\hline & 2 & 3 & 3 & 3 & 3 & 4 & 4 & 5 & 5 \\
\hline & 3 & 2 & 3 & 3 & 4 & 4 & 4 & 5 & 5 \\
\hline \multirow{3}{*}{4} & 1 & 3 & 4 & 4 & 4 & 4 & 4 & 5 & 5 \\
\hline & 2 & 3 & 4 & 4 & 4 & 4 & 4 & 5 & 5 \\
\hline & 3 & 3 & 4 & 4 & 5 & 5 & 5 & 6 & 6 \\
\hline \multirow{3}{*}{5} & 1 & 5 & 5 & 5 & 5 & 5 & 6 & 6 & 7 \\
\hline & 2 & 5 & 6 & 6 & 6 & 6 & 7 & 7 & 7 \\
\hline & 3 & 6 & 6 & 6 & 7 & 7 & 7 & 7 & $\varepsilon$ \\
\hline \multirow{3}{*}{6} & 1 & 7 & 7 & 7 & 7 & 7 & 8 & 8 & 9 \\
\hline & 2 & 7 & 8 & 8 & 8 & 8 & 9 & 9 & 9 \\
\hline & 3 & 9 & 9 & 9 & 9 & 9 & 9 & 9 & 9 \\
\hline
\end{tabular}


a.) Skor postur kerja grup A berdasarkan tabel 17. di atas adalah 4.

b.) Skor aktivitas. Aktivitas dilakukan berulang-ulang, lebih dari 4 kali/menit dengan skor $=1$.

c.) Skor beban. Beban $<2 \mathrm{~kg}$ dengan skor $=0$.

d.) Total skor untuk grup A adalah $3+1+3=7$.

2.) Postur tubuh grup $B$ :

a.) Postur tubuh bagian leher (neck). Leher membentuk sudut $10^{\circ}-20^{\circ}$ diberi skor $=2$.

b.) Postur tubuh bagian batang tubuh (trunk). Batang tubuh membentuk sudut $20^{\circ}-60^{\circ}$ diberi skor $=$ 3.

c.) Postur tubuh dibagian kaki (legs). Kaki tidak seimbang dengan skor $=2$.

Tabel 18. Grup B untuk Postur Berdiri Mengangkang Menyimpan Produk Kemasan Jerigen

\begin{tabular}{|c|c|c|c|c|c|c|c|c|c|c|c|c|}
\hline \multirow{4}{*}{ Neck } & \multicolumn{12}{|c|}{ Trunk } \\
\hline & \multirow{2}{*}{\multicolumn{2}{|c|}{$\begin{array}{c}1 \\
\text { Legs }\end{array}$}} & \multirow{2}{*}{\multicolumn{2}{|c|}{$\begin{array}{c}2 \\
\text { Legs }\end{array}$}} & \multirow{2}{*}{\multicolumn{2}{|c|}{$\begin{array}{l}\text { (3) } \\
\text { Legs }\end{array}$}} & \multirow{2}{*}{\multicolumn{2}{|c|}{$\begin{array}{c}4 \\
\text { Legs }\end{array}$}} & \multirow{2}{*}{\multicolumn{2}{|c|}{$\begin{array}{c}5 \\
\text { Legs }\end{array}$}} & \multirow{2}{*}{\multicolumn{2}{|c|}{$\begin{array}{c}6 \\
\text { Legs }\end{array}$}} \\
\hline & & & & & & & & & & & & \\
\hline & 1 & 2 & 1 & 2 & 1 & (2) & 1 & 2 & 1 & 2 & 1 & 2 \\
\hline 1 & 1 & 3 & 2 & 3 & 3 & 4 & 5 & 5 & 6 & 6 & 7 & 7 \\
\hline (2) & 2 & 3 & 2 & 3 & 4 & (5) & 5 & 5 & 6 & 7 & 7 & 7 \\
\hline 3 & 3 & 3 & 3 & 4 & 4 & 5 & 5 & 6 & 6 & 7 & 7 & 7 \\
\hline 4 & 5 & 5 & 5 & 6 & 6 & 7 & 7 & 7 & 7 & 7 & 8 & 8 \\
\hline 5 & 7 & 7 & 7 & 7 & 7 & 8 & 8 & 8 & 8 & 8 & 8 & 8 \\
\hline 6 & 8 & 8 & 8 & 8 & 8 & 8 & 8 & 9 & 9 & 9 & 9 & 9 \\
\hline
\end{tabular}

a.) Skor postur tubuh grup B berdasarkan tabel 18. di atas adalah $=5$.

b.) Skor aktivitas. Aktivitas dilakukan berulang-ulang, lebih dari $4 \mathrm{kali} / \mathrm{menit}$ dengan skor $=1$.

c.) Skor beban. Beban $<2 \mathrm{~kg}$ dengan skor $=3$.

d.) Total skor untuk grup A adalah $5+1=6$.

3.) Skor akhir dapat dilihat pada tabel 19. di bawah ini.

Tabel 19. Skor Grup C Postur Kerja Berdiri Mengangkang Menyimpan Produk Kemasan Jerigen

\begin{tabular}{cccccccc}
\hline Skor & & \multicolumn{5}{c}{ Skor Grup B } & \\
Grup A & 1 & 2 & 3 & 4 & 5 & 6 & 7 \\
\hline 1 & 1 & 2 & 3 & 3 & 4 & 5 & 5 \\
2 & 2 & 2 & 3 & 4 & 4 & 5 & 5 \\
3 & 3 & 3 & 3 & 4 & 4 & 5 & 6 \\
4 & 3 & 3 & 3 & 4 & 5 & 6 & 6 \\
5 & 4 & 4 & 4 & 5 & 6 & 7 & 7 \\
6 & 4 & 4 & 5 & 6 & 6 & 7 & 7 \\
7 & 5 & 5 & 6 & 6 & 7 & 7 & 7 \\
8 & 5 & 5 & 6 & 7 & 7 & 7 & 7 \\
\hline
\end{tabular}

Skor akhir untuk aktivitas berdiri dengan mengangkang dan menyimpan produk kemasan jerigen adalah 6 dengan resiko sedang dan tindakan dalam waktu dekat. Dari penjelasan diatas dapat dilihat secara ringkas pada gambar 5. RULA employee assesment worksheet dibawah ini.

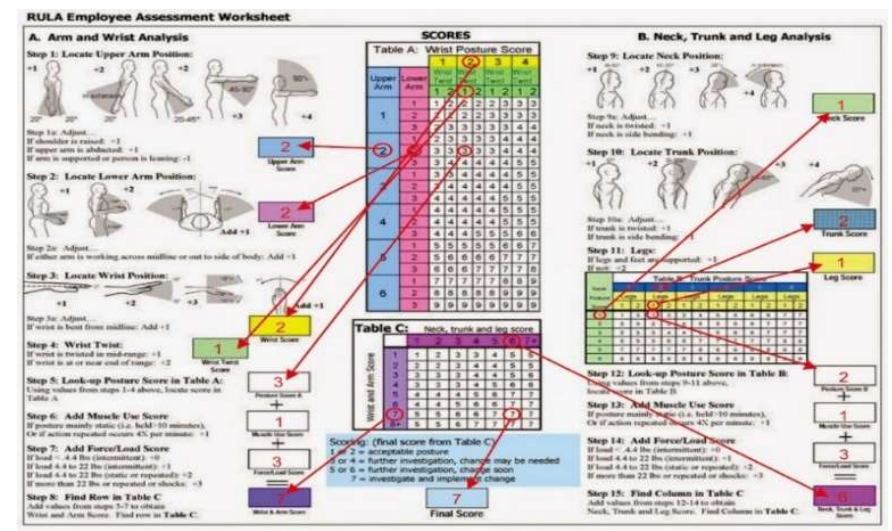

Gambar 5. RULA Employee Assesment Worksheet 
Rekapitulasi hasil perhitungan dengan menggunakan RULA employee assesment worksheet, diantaranya: Tabel 20. Rekapitulasi Hasil Perhitungan dengan RULA

\begin{tabular}{clccc}
\hline No & \multicolumn{1}{c}{ Postur Kerja } & Akhir Skor & Level & Tindakan Perbaikkan \\
\hline 1 & $\begin{array}{l}\text { Berdiri dengan mengangkat produk kemasan } \\
\text { jerigen }\end{array}$ & 7 & Tinggi & Sekarang juga \\
2 & $\begin{array}{l}\text { Beridiri membungkuk saat menyimpan produk } \\
\text { kemasan jerigen }\end{array}$ & 7 & Tinggi & Sekarang juga \\
3 & $\begin{array}{l}\text { Berdiri mengangkang menunggu produk } \\
\text { kemasan jerigen dating }\end{array}$ & 4 & Kecil & Beberapa waktu kedepan \\
4 & $\begin{array}{l}\text { Berdiri mengangkang dengan mengangkat } \\
\text { produk kemasan jerigen }\end{array}$ & 7 & Tinggi & Sekarang juga \\
5 & $\begin{array}{l}\text { Berdiri mengangkang dan menyimpan produk } \\
\text { kemasan jerigen ke atas pallet }\end{array}$ & 6 & Sedang & Dalam waktu dekat \\
\hline
\end{tabular}

Berdasarkan perhitungan yang telah dilakukan maka dibuatlah analisis pemecahan masalah (Wignyosubroto, 1995) sebagai berikut:

a. Penggunaan alat pelindung diri (APD) berupa sarung tangan dan back support untuk mengurangi beban dan rasa sakit operator.

b. Penambahan fasilitas kerja berupa penambahan panjang conveyor dengan menurunkan tambahan conveyor tersebut. Kemudian menambahkan meja rolling dengan dimensi ukuran sama dengan pallet dan dengan tinggi $31 \mathrm{~cm}$, atau sama dengan tinggi tempat pallet dan tinggi pallet tersebut. Hal ini dapat membantu operator bagian palletizing dalam menyusun produk kemasan jerigen dengan berat $24 \mathrm{~kg}$, dan tanpa harus mengangkat jerigen tersebut. Dengan penambahan fasilitas kerja berupa penambahan panjang conveyor dengan menurunkan tambahan conveyor tersebut, kemudian menambahkan meja rolling dengan dimensi ukuran sama dengan pallet dan dengan tinggi $31 \mathrm{~cm}$, atau sama dengan tinggi tempat pallet dan tinggi pallet tersebut. Lebih mudah dalam menyusun produk kemasan jerigen karena mengurangi beban dari jerigen tanpa mengangkat jerigen tersebut. Perbaikan postur kerja dengan penambahan bangku kecil dapat dilihat pada gambar 6. di bawah ini.

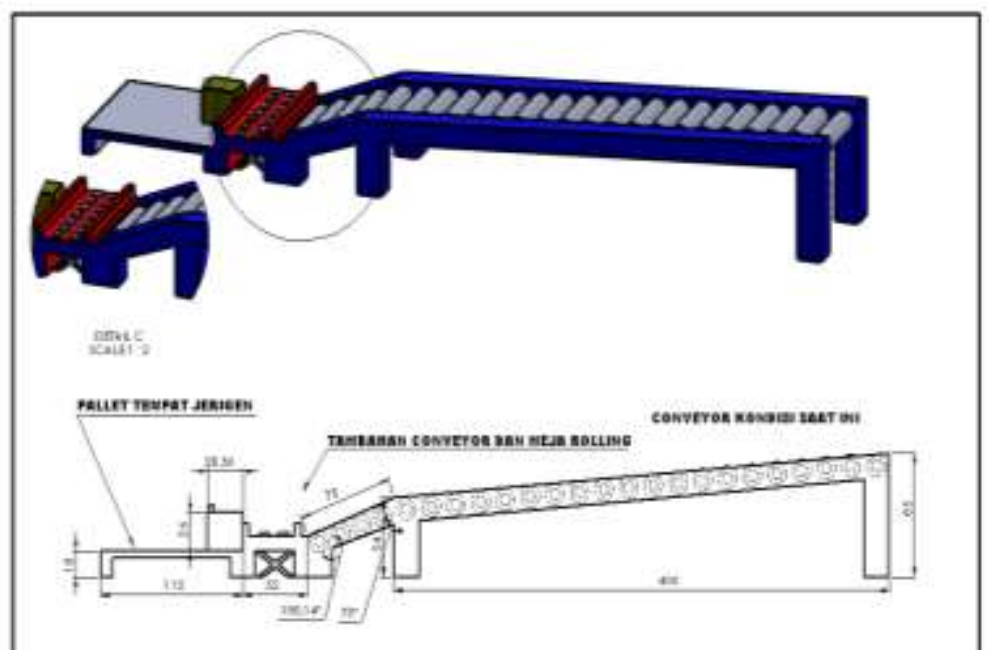

Gambar 6. Perbaikan penambahan Conveyor

Dengan penambahan fasilitas ini, operator tidak perlu mengangkat produk kemasan jerigen dari ketinggian conveyor ke pallet yang sudah disediakan disamping meja rolling. Evaluasi dengan menggunakan metode RULA belum bias dilakukan akan tetapi dengan mengurangi beban dan merubah metode kerja ini sudah pasti akan mengurangi skor RULA yang ada dan terjadi ketika belumada penambahan fasilitas.

c. Pembuatan standar operasional prosedur proses palletizing. Saat ini PT. XYZ khususnya bagian packing line $\mathrm{D}$, tidak mempunyai standar operasional prosedur (SOP) untuk proses pekerjaan yang dilakukan. Oleh kerena itu, memberikan rekomendasi pembuatan SOP untuk proses pekerjaan palletizing, ini akan memberikan dampak positif kepada operator karena dengan adanya stadar proses yang dilakukan menjadi panduan untuk operator. Pembuatan SOP untuk proses penyusunan barang jadi jerigen $24 \mathrm{~kg}$, dibuatkan setelah proses pembuatan fasilitas tambahan untuk conveyor yang ada. Karena pembuatan SOP harus dengan percobaan. Oleh karena itu pembuatan SOP akan menjadi rekomenasi perbaikan kerja agar proses kerja yang dilakukan tidak menyimpang dari SOP yang akan dibuat dan tidak mengakibatkan cedera pada operator. 


\section{Simpulan}

Berdasarkan pengolahan data dan pembahasan analisis pada penelitian ini, maka dapat diambil kesimpulan sebagai berikut:

a. Postur kerja yang memiliki level resiko tertinggi adalah postur kerja berdiri dengan mengangkat produk kemasan jerigen, berdiri membungkuk saat menyimpan produk kemasan jerigen, dan berdiri mengangkang dengan mengangkat produk kemasan jerigen dengan skor 7. Selain itu, postur kerja berdiri mengangkang saat menyimpan produk kemasan jerigen keatas pallet dengan skor 6 yang memiliki level resiko sedang juga harus diperbaiki dalam waktu dekat.

b. Tinggi conveyor dengan sisi belakang $85 \mathrm{~cm}$ dan sisi depan $54 \mathrm{~cm}$ sementara tinggi pallet yang hanya 15 $\mathrm{cm}$ sangat mempengaruhi postur kerja operator bagian palletizing. Hal ini menyebabkan operator sulit untuk mengangkat dan menyimpan produk kemasan jerigen dengan berat $24 \mathrm{~kg}$ keatas pallet yang pada akhirnya operator harus melakukan postur kerja yang tidak alami. Untuk membantu proses palletizing operator, perlu diberi fasilitas tambahan berupa penambahan panjang conveyor dan menambah meja rolling. Penambahan panjang conveyor dan meja rolling tersebut untuk mempermudah operator bagian palletizing sehingga diharapkan akan menurunkan skor akhir.

c. Berdasarkan hasil penelitian yang dilakukan pada bagian palletizing dan dari hasil Standard Nordic Questionnaire, operator sering mengalami sakit otot tulang belakang sehingga perlu penggunaan Alat Pelindung Diri (APD) berupa back support untuk mengurangi resiko cedera otot. Kondisi saat ini operator tidak menggunakan back support.

\section{Daftar Pustaka}

Lueder, R. A. (1996). Proposed RULA for Computer Users. Proccedings of The Ergonomics Summer Workshop (hal. 1-8). San Fransisco: UC Berkeley Center for Occupational \& Enviromental Health Continuing Program.

Nurmianto, E. (1996). Ergonomi Konsep Dasar dan Aplikasinya. Surabaya: PT. Guna Widya.

Nurmianto, E. (2004). Ergonomi Konsep Dasar dan Aplikasinya. Surabaya: PT. Guna Widya.

Pangabean, M. (2009). Analisis Postur Kerja dengan Metode RULA pada Pegawai Bagian Pelayanan Perpustakaan USU Medan. Jurnal Tugas Sarjana, Program Studi Pendidikan Sarjana Teknik Industri Departement Teknik Industri, Fakultas Teknik, Universitas Sumatera Utara, Medan, 50-62.

Pourmahabadian, M., Akhavan, M., \& Azam, K. (2008). Investigation of Risk Factors of Work-Related UpperLimb Mosculoskeletal Disorders in a Pharmaceutical Industry. Journal of Applied Sciences 8, 1262-1267. Santoso, G. (2004). Ergonomi Manusia. Makkasar: Prestasi Pustaka.

Tarwaka, S., \& Sudiajeng, L. (2004). Ergonomi untuk Keselamatan, Kesehatan Kerja dan Produktivitas. Surakarta: Uniba Press.

Wignyosubroto, S. (1995). Ergonomi, Studi Gerak dan Waktu, Teknik Analisis untuk Peningkatan Produktivitas Kerja. Jakarta: PT. Guna Widya. 